\title{
Markedness, Faithfulness, Vowel Quality and Syllable Structure in French ${ }^{1}$
}

\author{
Caroline Féry
}

\section{Introduction}

The goal of this paper is twofold: first it reviews the distributional properties of tense and lax vowels in a relatively standard dialect of Northern French which still contrasts vowel length, and second, on the basis of these data, it examines the interaction between markedness and faithfulness constraints in Optimality Theory (OT, Prince \& Smolensky 1993). The intricate interplay between vowel quality, syllable structure and cooccurrence restrictions between vowels and consonants that one observes in French makes it an ideal language for exploring the interactions between the two kinds of constraints.

As a general tendency, it can safely be assumed that tense vowels appear in open syllables and lax vowels in closed syllables; thus, that generalization (1) which has repeatedly been observed for the Germanic languages holds in French, too (see van der Hulst 1984 and Kager 1989 for Dutch, Moulton 1962, Wiese 1996 and Féry 1997 for German, Hammond 1997 for English).

(1) Tense vowels appear in open syllables and lax vowels in closed syllables.

However, the situation is complicated by the fact that only mid vowels contrast a tense and a lax variant - at least in the dialect discussed here - and that the distinction is made (nearly) exclusively in the phrase-final syllable, also preconsonantally. Further complications arise because of the effect of idiosyncratic cooccurrence restrictions that override (1). Some of these difficulties are eliminated by a phonologically abstract model of the syllable structure. In the analysis developed below, it is assumed that French has semisyllables, confined to the word-final position, which function as onsets of

\footnotetext{
Parts of this work have been presented at Rutgers University, Cornell University, Laboratoire de Phonétique de Paris and the International Phonology Conference in Nantes between April 2000 and May 2001. I would like to thank the audience, as well as or especially Gilles Boyé, Kirsten Brock, Nick Clements, François Dell, Tonio Green, Marc van Oostendorp, Annie Rialland, Hubert Truckenbrodt, Ruben van de Vijver and Richard Wiese for feedback. This work is part of the DFG Forschergruppe 'Conflicting Rules' of the University of Potsdam.
} 
nucleusless syllables. This explains why tense vowels can be in apparently (i.e. phonetically) closed syllables.

As for the second goal, this paper illustrates that roughly three types of constraints interact in grammar. First, there are markedness constraints of a general type dealing with universal tendencies. Constraints like OnSET, NOCODA, NoVoICED OBSTRUENT and the like are of this type. We will see that the constraints which work together to allow the structures in (1) to surface are of this type, as well. Second, more specific markedness constraints, expressing particular effects like language-dependent cooccurrence restrictions between vowels and consonants, are present in the grammar, as well. Finally, in the case at hand, some occurrences of lax, tense and long vowels are best understood as arising as a consequence of faithfulness to properties specified in the input. Constraints are organized in the following way: the more specific the constraints are, the higher ranking they need to be. In the absence of activity of the specific constraints, fulfillment of the general constraints lead to "emergence of the unmarked".

The paper is organized as follows. The first section gives an overview of the French segments and of the data involving the mid vowels. The second section introduces the syllable structure of French. The last sections concentrate on the tense/lax alternation in the mid vowels and show how OT can deal with them.

\section{The French segments}

\subsection{Segment inventory}

The inventory of General French (GF) segments is given in (2) for consonants, and in (3) for vowels (see Plénat 1987, Tranel 1987, 1995 and many others for slightly different proposals). The plosives contrast three places of articulation, and the fricatives four, at least if some instances of $[R]$ are analyzed as fricatives. The fact that three different instances of $[R]$ are listed in (2) may be surprising, but $[R],[\chi]$ and $[B]$ are different sounds with different properties, even though the different articulations of $[R]$ are in complementary distribution, which seems to make them allophones of each other. Additionally, French has four nasals, two liquids and three glides, but no laryngeals.

As for the vowels, it is well known that French contrasts more vowels than most languages. In the dialect described here, the mid vowels each have a tense and a lax variant, thus $[\mathrm{e} / \varepsilon],[\mathrm{o} / \mathrm{\supset}]$, and $[\varnothing / œ]$, while no other vowel has two variants. It thus differs from Quebec French and other dialects of French in which high vowels also contrast for tenseness.

French also has underlying nasal vowels, as in the words cinq 'five', honte 'shame' and banque 'bank', though most occurrences of these nasal vowels alternate with a 
sequence of an oral vowel plus nasal consonant. Most speakers of French have just three

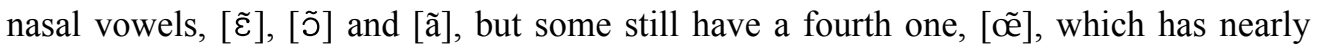
disappeared in the standard language.

(2) Inventory of French consonants

\begin{tabular}{|l|c|c|c|c|c|c|}
\hline & Labial & Alveolar & Alveopalatal & Palatal & Velar & Uvular \\
\hline Plosives (voiceless) & $\mathrm{p}$ & $\mathrm{t}$ & & & $\mathrm{k}$ & \\
\hline Plosives (voiced) & $\mathrm{b}$ & $\mathrm{d}$ & & & $\mathrm{g}$ & \\
\hline Fricatives (voiceless) & $\mathrm{f}$ & $\mathrm{s}$ & $\mathrm{J}$ & & & $\chi$ \\
\hline Fricatives (voiced) & $\mathrm{v}$ & $\mathrm{z}$ & 3 & & & $\mathrm{~B}$ \\
\hline Nasals & $\mathrm{m}$ & $\mathrm{n}$ & & $\mathrm{n}$ & $\mathrm{y}$ & \\
\hline Liquids & & 1 & & & & $\mathrm{R}$ \\
\hline Glides & $\mathrm{w}, \mathrm{U}$ & & & $\mathrm{j}$ & & \\
\hline
\end{tabular}

(3) The vocalic space in French

i $y$

e $\varnothing$

$\varepsilon \tilde{\varepsilon} \propto \tilde{\varepsilon}$ $\mathrm{u}$

O

ว

ว ว

a $\quad \tilde{a} \quad a$

Most speakers just have one oral [a]. However, in some dialects of French, a lexical distinction between two $a$-sounds still exists, especially in word-final position (see Delattre 1957, Meisenburg \& Selig 1998). Some words with [a] and some with [a] are listed in (4) (from Léon 1972).

(4) [a]: gazon 'lawn', marron 'chestnut', rat 'rat', tache 'stain', arabe 'arab', table 'table'

[a]: bâtir 'to build', château 'castle', gâteau 'cake', bâton 'stock', crabe 'crab'

Schwa in French has a complex pattern of realization vs. non-realization, but it is beyond the scope of this paper to give an account of this pattern. The interested reader is referred to Anderson (1982), Basbøll (1978), Charette (1991), Morin (1987, 1988), Noske (1984), van Oostendorp (1999) and Rialland (1986, 1999), among others. 


\subsection{The alternation $\mathrm{o} \sim \mathrm{ç}$ (mid back rounded vowels)}

This section and the two following ones describe the contexts in which the tense and the lax variants of the mid vowels appear. We will consider the alternations between [ç] and $[o],[œ]$ and $[\varnothing]$, and $[\varepsilon]$ and $[e]$ in turn. A puzzling fact is the difference between the contexts in which the lax and the tense versions of the mid vowels appear. While the tendency expressed in (1) is clearly visible for each pair of vowels, the details of the occurrence of the individual vowels differ in the three cases.

Consider first the nonalternating environments for [o] in (5). The lax variant [ç] is not allowed in a Phonological Phrase final position, which is usually assumed to be the stressed position in French (see, however, Féry 2001 for a different analysis). ${ }^{2}$ In this position only the tense variant $[\mathrm{o}]$ is possible.

(5) No [c] in open final syllables, but only [o]:

boulot 'job', rideau 'curtain', seau 'bucket', sot 'silly'

Some stems have alternating o-sounds, depending on whether the vowel is in a closed or an open syllable. If the vowel is word final, it is tense, but if it is in a closed syllable, it is lax (see (6)).

(6) Alternations $[\mathrm{o}] \sim[\mathrm{ç}]$

sot $\sim$ sotte 'silly, masc., fem.' $\quad$ idiot $\sim$ idiote 'idiotic, masc., fem.'

rigolo $\sim$ rigolote 'funny, masc., fem.' boulot 'work, N' boulotte 'works, infl. V'

culot 'cheek' $\sim$ culotte 'pants' gigot 'leg' $\sim$ gigotte 'wriggles, infl. V'

Some final consonants influence the quality of the preceding vowel, as in the examples in (7). Before $[\mathrm{z}]$, only [o] is found, but before $[\mathrm{r}],[\mathrm{g}],[\mathrm{n}]$ and $[\mathrm{y}]$, the class of voiced dorsal consonants, only the lax variant [ç] is possible (see Léon 1972).

(7) No alternations

a. $[\mathrm{o}]$ before $[\mathrm{z}]$

[z]: cause 'cause', chose 'thing', ose 'dares', rose 'rose', dose 'dosis'

b. [ç] before [в], [g], [n] and [y]

[в]: corp 'body', dort 'sleeps', or 'gold', corde 'rope', forme 'form'

[g]: vogue 'mode', pirogue 'pirogue', analogue, grog, dogue 'mastiff'

[n]: cigogne 'stork', cogne 'knocks', grogne 'moans', rogne 'bad temper'

[y]: gong, King Kong

2 It may occur in a hiatus position, as in boa, Noé 'Noah', Noël 'Christmas', Boétie 'name', oasis, and coopératif, but this is not the final or "stressed" syllable of the word. In unstressed positions, many realizations are neutralized and can be either lax or tense, or have an in-between quality. 
In the remaining contexts, both variants of the mid back vowel are possible, at least in GF. We are confronted here with lexical variation. ${ }^{3}$

(8) Lexical contrasts

\begin{tabular}{|c|c|c|c|}
\hline$[\mathrm{c}]$ & [o] & {$[c]$} & [o] \\
\hline sotte 'silly & saute 'jumps' & roc 'rock' & rauque 'hoarse' \\
\hline bosse 'hump & Beauce 'a place name' & poche 'pocket' & gauche 'left' \\
\hline lov & sauve 'saves' & loge 'is quartered' & aug \\
\hline $\begin{array}{l}\text { bonne 'good' } \\
\text { sole 'sole' }\end{array}$ & $\begin{array}{l}\text { Beaune 'a place name' } \\
\text { saule 'willow' }\end{array}$ & pomme & paum \\
\hline
\end{tabular}

The distribution of the lax and the tense variants of the mid back rounded vowels is summed up in (9).

(9) Generalizations

a. Only [o] in an open syllable. Preferably [0] in a closed syllable, see (5) and (6).

b. Only the tense back mid vowel [o] before [z], see (7a).

c. Only the lax back mid vowel [o] before voiced dorsal consonants, see (7b).

d. Otherwise, in word-final position before a consonant, both variants are allowed, see

$(8)$.

\subsection{The alternation $\varnothing \sim \propto($ mid front rounded vowels)}

The alternation between the mid front rounded vowels is conditioned in part by factors different from those just demonstrated for the back mid vowels. The first observation, however, agrees with what has been observed for the o-sounds. Word-finally, only the tense variant is allowed.

(10) No [œ] in open final syllables, but only [ø]:

peu 'few', feu 'fire', queue 'tail', creux 'hollow', ceux 'those', noud 'knot', heureux 'happy'

3 In unstressed syllables, the quality of the vowel depends to some extent on the quality of the stem vowel, as in (i) and (ii). In other cases, it depends on the kind of syllable it is in. If the syllable is open, it is tense (iii), otherwise, it is lax (iv). It seems that the orthography plays an important role in the pronunciation of the o-sound: $<\hat{\mathrm{o}}>,<\mathrm{au}>$ and $<\mathrm{eau}>$, for instance, are mostly pronounced as [o].

(i) [o]: beau 'handsome'/beauté 'beauty', haut 'high'/hauteur 'height', faux 'wrong'/fauteur 'troublemaker'

(ii) [ग]: botte 'boot'/botté 'in boots', sotte 'silly'/sottise 'silliness', bosse 'hump'/bossu 'hunchbacked', note 'note'/noté 'noted'

(iii) [o]: auto 'car', aussi 'also', sauvé 'saved'

(iv) [0]: sortir 'to go out', colmater 'to fill in' 
There is also an alternation between the two variants in closed and open syllables, though the contexts are more limited than for the o-sounds. Some of them are shown in (11).

(11) Alternations $[\varnothing] \sim[œ]$

peureux $[\varnothing]$ 'fearful' $\sim$ peur [œ] 'fear'

heureux [ø] 'happy' bonheur [œ] 'happiness'

veut $[\varnothing]$ 'wants, 3rd pers. sg.' veulent [œ] 'want, 3rd pers. pl.'

The main difference between the two alternations involves the environments in which only one of the variants is allowed. The correct generalization seems to be the following: Before a coronal obstruent, only $[\varnothing]$ is allowed (12). Otherwise, [œ] is generally found (13).

(12) Only $[\varnothing]$ is allowed before a coronal obstruent

before [t]: émeute 'riot', feutre 'felt', thérapeute 'therapist', meute 'pack'

before [z]: creuse 'hollow, fem.', gueuse 'lass', heureuse 'happy, fem.', danseuse 'dancer, fem.'

before [3]: Maubeuge 'a place name'

before [d]: Eudes 'a first name'

(13) Only [œ] before other consonants

before [R]: heure 'hour', beurre 'butter', sœur 'sister', bonheur 'happiness'

before [j]: feuille 'leaf', cueille 'picks', œil 'eye'

before [f]: œuf 'egg', bœuf 'ox', veuf 'widow', neuf 'new'

before [v]: veuve 'widow, fem.', neuve 'new, fem.'

before [p]: peuple 'folk'

before [b]: meuble 'furniture'

Some marginal alternation contexts appear in (14), showing that [ø] can also appear before consonants other than a coronal obstruent. One member of each pair is not part of the inventory of the author (and of most other native speakers consulted) and is therefore in parentheses. In these idiolects, the contrast is neutralized to the variant not in parentheses.

$\varnothing$

(veule 'of a weak character')

meule 'mill'

(jeûne 'fast')

meugle 'moos, infl. V' $œ$

veulent 'want, subj.'

(meule 'stack')

jeune 'young'

aveugle 'blind' 
In some loanwords [œ] replaces the English vowel $[\Lambda]$, which is not part of the French vowel inventory. The sequence [œt] is perceived as foreign.

(15) [œ] in loanwords: club, hold-up, cut

Moreover, there is no difference between the quality of [œ] and schwa, even if speakers of French have clear intuitions about them, mostly as a consequence of the orthography and the distribution. Schwa is usually written $<\mathrm{e}>$, whereas [œ] is written $<\mathrm{eu}>$ or $<œ u$.

Leaving schwa and the vowel replacing $[\Lambda]$ in loanwords aside, the generalizations that emerge for the distribution of the mid front rounded vowels are the following.

\section{(16) Generalizations}

a. Only [ø] in a final open syllable. Preferably [œ] in a closed syllable, see (10) and (11).

b. Before a coronal obstruent, only [ø] is allowed, see (12).

c. Otherwise, in word-final position before a consonant, nearly only [œ], though some rare lexical pairs still exist, see (13) and (14).

\subsection{The alternation $\mathrm{e} \sim \varepsilon$ (mid front unrounded vowels)}

Front unrounded vowels are different again. First and most puzzling, both the tense [e] and the lax variant $[\varepsilon]$ appear at the end of a word in an open syllable (at least in the standard Northern dialect under consideration). Minimal pairs are abundant, as exemplified in (17).

(17) Lexical contrast in word final position

\begin{tabular}{ll}
$\quad[\mathrm{e}]$ & \multicolumn{1}{c}{$[\varepsilon]$} \\
gré 'taste' & grès 'sandstone' \\
vallée 'valley' & valet 'butler' \\
aller 'to go' & allais 'went' \\
épée 'dagger' & épais 'thick' \\
poignée 'handful' & poignet 'wrist'
\end{tabular}

In spite of this fact, there is a strong tendency for [e] to be in an open syllable and for $[\varepsilon]$ to be in a closed syllable. Here, too, examples are plentiful (at least before [R]). The pairs in (18) are truly alternating pairs. 


\section{(18) Alternations}

premier première 'first, masc., fem.'

dernier dernière 'last, masc., fem.'

boulanger boulangère 'baker, masc., fem.'

charnier 'grave' $\sim$ charnière 'hinge'

Finally and unexpectedly, no [e] is found before a consonant word finally. ${ }^{4}$ In this position only $[\varepsilon]$ is possible.

(19) Only $[\varepsilon]$ in word-final closed syllables

elle 'she'

cette 'this, fem.'

cèpe 'cep'

bec 'beak'

The generalizations arising from the data discussed here are formulated in (20).

\section{(20) Generalizations}

a. Both $[\mathrm{e}]$ and $[\varepsilon]$ in an open syllable, see (17).

b. No [e], but always $[\varepsilon]$ before a final consonant. [e] is allowed only in an open syllable, see (18) and (19).

To sum up section 2, it can safely be assumed that generalization (1) holds in French. This is particularly true for the pairs of rounded vowels and less so for the unrounded vowels. However, the image is not perfect, since, at the surface, one observes many tense vowels in apparently closed syllables (and lax $[\varepsilon]$ is found in word-final open syllables). Moreover, some cooccurrence restrictions, like those shown in (7) and (12), render the generalization difficult to maintain in many cases. The next sections introduce a theoretical analysis explaining some of the deviant facts.

\section{The French Syllable}

Since the OT account of the distribution of the lax and tense vowels in French to be developed below relies on a rather abstract analysis of syllable structure and on the

4 Gilles Boyé (p.c.) observes that the first class of verbs builds its infinitives without phonetic [R]. This contrasts with all other classes of verbs, which realize $[R]$. Assuming that the quality of the vowel cannot be changed, $[R]$ is impossible as a closing consonant, since it would violate the prohibition of $[\mathrm{e}]+$ consonant. The only viable solution is to delete $[\mathrm{R}]$. 
assumption of the existence of semisyllables, both concepts must be introduced. This is the aim of the present section. The focus will be on the coda, but onsets and nuclei will also be briefly considered.

First, onsets can be empty in French, which means that they are optional. Onsets have maximally three positions and always have an increasing sonority, as shown in (21). If the first segment is a stop, as in (21a), the second one may be a fricative, a liquid or a glide. In case the first segment is a fricative, as in (21b), the second one can be a liquid or a glide. And if the first one is a sonorant, as in $(21 \mathrm{c})$, the second one is also a sonorant, but of higher sonority. Whereas $[\mathrm{w}]$ and $[\mathrm{y}]$ can be part of a triconsonantal onset, as in truie 'sow', bruit 'noise', broie 'crushes', and cloitre 'cloister', this is impossible for [j]. In brillant 'bright', plier 'to fold', triangle 'triangle', and the like, [i] never becomes a glide. An explanation could be that the sonority distance between a sonorant and [j] is not sufficient for them to be part of one onset, while the sonority distance between a sonorant and $[\mathrm{w}]$ is. In other words, $[\mathrm{j}]$ is more consonantal (less sonorous) than $[\mathrm{w}]$ and $[\mathrm{u}]^{5}$

\section{(21) Onsets}

a. pх (près), bь (bras 'arm'), gl (glace 'ice'), pw (pois 'pea'), ky (cuire 'to cook'), by (buisson 'bush'), dj (diable 'devil'), gБw (groin 'snout'), bRy (bruit 'noise')

b. f $\chi$ (frère 'brother'), vв (vrai 'true'), fl (fleur 'flower'), sw (soie 'silk'), zw (zouave 'Zouave'), 3w (joie 'joy'), fy (fuite 'flight'), Jj (chien 'dog')

c. Iw (loi 'law'), ny (nuit 'night'), Rч (ruine 'ruin'), mj (miel 'honey'), rj (rien 'nothing')

Onsets always respect the Sonority Sequencing Principle formulated in (22a). The sonority hierarchy, following Clements (1990), is shown in (22b).

\section{(22) Sonority}

\section{a. Sonority Sequencing Principle}

The most sonorous segment of a syllable is the nucleus. From the nucleus to the edges of the syllable, segments are not of increasing sonority.

\section{b. Sonority Hierarchy}

$\begin{array}{lllll}\text { Stops } & \text { Fricatives } & \text { Nasals } & \text { Liquids }(1, \mathrm{r}) \quad \text { Glides } & \text { Vowels }\end{array}$

\footnotetext{
This result is compatible with Davis \& Hammond's (1995) for Californian English. In this language, [w] is part of the onset and [j] part of the nucleus (it is also part of a diphthong).
} 
Turning now to the postvocalic consonants, the picture is more complex. If more than one consonant follows the nucleus, the consonants can be of decreasing or of increasing sonority, and the sonority can also form a plateau, as shown in (23).

(23) Codas

\begin{tabular}{|c|c|c|}
\hline a. & Sonorant + Stop & Stop + Sonorant \\
\hline $\mathrm{pr}, 1$ & harpe 'harp', Alpes 'Alps' & âpre 'rough', couple 'couple' \\
\hline b r, 1 & Serbe 'Serb', (Elbe) & arbre 'tree', cable 'cable' \\
\hline t $\mathrm{r}, 1$ & $\begin{array}{l}\text { verte 'green' } \\
\text { moulte 'many' }\end{array}$ & quatre 'four' \\
\hline $\mathrm{d} \mathrm{r}, 1$ & garde 'keep' & cadre 'frame' \\
\hline $\mathrm{k} \mathrm{r}, 1$ & $\begin{array}{l}\text { orque 'killer whale' } \\
\text { calque 'tracing' }\end{array}$ & ocre 'ocher', siècle 'century' \\
\hline $\mathrm{g} \mathrm{r}, 1$ & $\begin{array}{l}\text { orgue 'organ' } \\
\text { algue 'seaweed' }\end{array}$ & aigre 'sour', aigle 'eagle' \\
\hline b. & $\mathbf{s}+$ Stop & Stop $+\mathbf{s}$ \\
\hline $\mathrm{ps}$ & & laps 'period of time' \\
\hline $\mathrm{k} \mathrm{s}$ & risque 'risk' & axe 'axis' \\
\hline c. & Sonorant + Fricative & Fricative + Sonorant \\
\hline f $r, 1$ & elf 'elf' & moufle 'mitten' \\
\hline $\mathrm{s} \mathrm{m}$ & clamse 'die' & materialisme 'materialism' \\
\hline d. & Sonor. + Sonor. & \\
\hline r 1 & merle 'blackbird' & \\
\hline e. & Sonority plateau & \\
\hline $\begin{array}{l}\text { two stops } \\
\text { two fricatives }\end{array}$ & $\begin{array}{l}\text { apte 'apt', acte 'act' } \\
\text { ours 'bear', offre 'offer' }\end{array}$ & \\
\hline
\end{tabular}

Two kinds of sequences which would be perfect from the point of view of the Sonority Sequencing Principle are nevertheless not allowed. First, a sequence consisting of a vowel plus a tautosyllabic nasal consonant followed by a consonant is usually excluded: such a sequence is replaced by a nasal vowel plus a consonant in nearly all cases (thus bonne [bçn]'good', bonté [bç,te] 'goodness'). The nonstandard clamser [klamse] 'to die' is an exception. Second, glides stand alone in the coda. There is no complex coda involving a glide, though there are complex onsets containing glides, as was shown in (21). To account for the distributional facts illustrated in (23), the syllable patterns in (24) and (25) are assumed. The syllable structure in (24) shows the 'normal' or default case. The onset can be absent, simple or complex, but the coda, if present, is always 
simple. To account for this, the syllable rime consists of at most two positions, one being the obligatory nucleus, the other the coda. Notice that the nucleus in French is always a vowel since French does not tolerate syllabic consonants.

(24) Core syllables

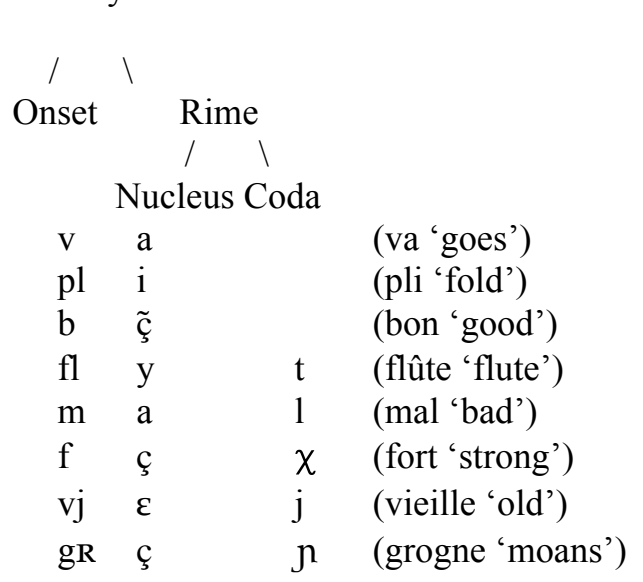

This agrees with Dell's (1995) analysis of the French syllable (see also Bouchard 1980). Plénat (1987) also proposes that rimes consist maximally of two positions, but he assumes that the two rime slots can be occupied by sonorants only. He thus analyzes [1] in $m a l$ [mal] as part of the core syllable, but excludes [t] in mat [mat] from the coda. His main argument is that sonorants tend to be fixed and obstruents to be latent; however, there are latent sonorants (like $[\mathrm{R}]$ in adjectives such as premier or infinitive verbs, or the nasal emerging in a liaison context) and there are also fixed obstruents. Notice at this point that the present paper does not investigate the delicate problem of the latent consonants but is restricted to the representation of the fixed consonants, as far as they play a role in the distribution of the mid vowels.

The second type of syllable is more complex and consists of two syllables, a core syllable and a semisyllable, as shown in (25).

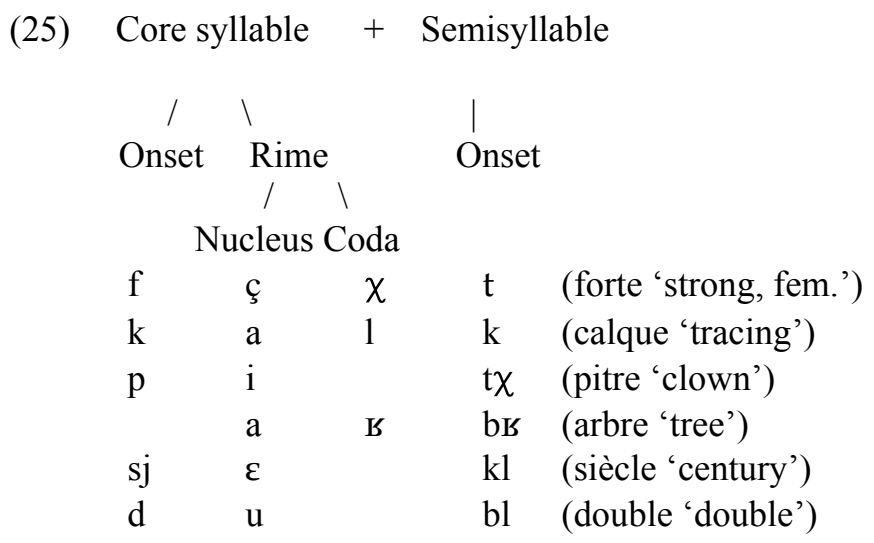


The addition of the semisyllables allows an analysis in which all syllables respect the Sonority Hierarchy, not only the core ones but also the semisyllables, which must be understood as onsets of nucleusless syllables. Rimes of core syllables have maximally two positions. Compare the first two words in (23), the final consonants of which are organized in a mirror fashion (as in most words in the list in (23)). In harpe, the dorsal fricative $[\chi]$ is the coda and $p$ is the semisyllable. In apre, on the other hand, both [p] and $[\chi]$ are parts of a semisyllable. The vowel [a] is longer in apre than in harpe, at least in case the word is in a stressed position (see below). The reason why [p] is part of the semisyllable and is not a coda in the case of apre has to do with the fact that onsets are maximized. The Onset Maximization Principle applies very rigidly in French, including in the semisyllables, and even - but to a lesser extent - across word boundaries. The other pairs of words in (23) behave similarly to harpe and apre, although not all 'slots' on the list are occupied. Notice that French can readily add a nucleus to a semisyllable in the form of an epenthetic schwa. The reasons motivating the insertion of schwa in some contexts are not the subject of this paper. Here we concentrate on the abstract phonological syllable as it would be pronounced in careful speech at the end of a phrase, thus one in which no schwa is realized.

The syllable contact law (Vennemann 1986) is respected. Thus a word like adroit is syllabified maximizing the onset segments of the second syllable, thus delivering a.droit ([dR] is a possible onset), but a word like ardoise is syllabified as ar.doise since [Rd] is not a possible onset. It would violate the Sonority Sequencing Principle.

Crucial for the following is the observation that words like contre [kõtR] 'against',

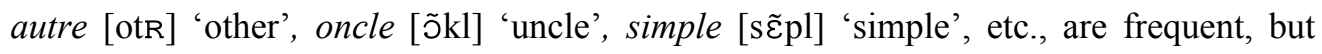
there are no words like *conrte [kõRt], *aurte [oRt], *onlque, [õlk], etc., in which the sonority of the two consonants is falling (see (26)). This distribution is an argument for the fact that the postvocalic consonants of this word are obligatorily relegated to a following semisyllable and cannot be distributed over the coda and a following onset. This is what is expected if the nasal vowels, as well as [o] and [ø], occupy two positions in the core syllable.

(26) No coda of decreasing sonority after bipositional (bimoraic) vowels

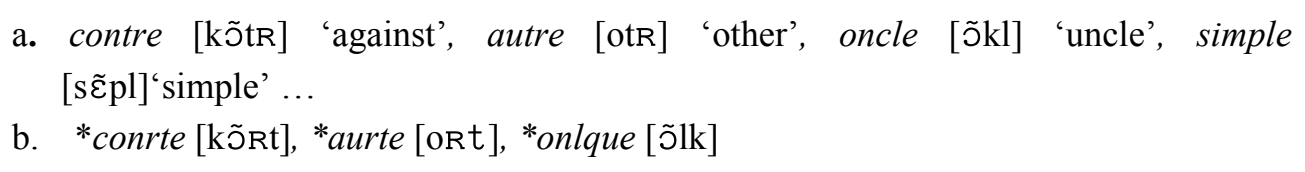




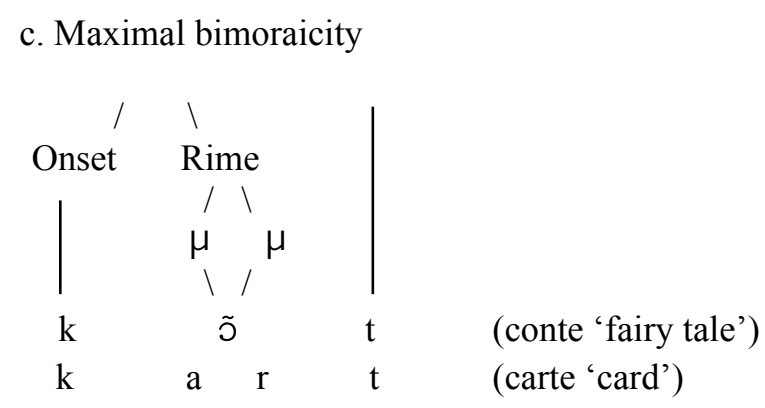

Thus the next generalization is that the rime consists of maximally two positions, expressed in moras, which can be distributed over a nucleus and a coda or occur in a long nucleus. If the nucleus occupies two moras, there is no place for a tautosyllabic coda. As the next step, consider an optimality-theoretic analysis of the French syllable using exclusively attested constraints, like the ones listed in (27). The basic idea of OT is very simple. It claims that Universal Grammar consists of a series of constraints, some of which are universally organized in a markedness hierarchy, but which are otherwise intrinsically unordered. The grammars of individual languages impose orderings upon this set of universal constraints, leading to differences between languages and thus to typological diversity. MAX in (27a) militates against deletion of segments, and DEP(ə) in (27b) against schwa epenthesis. These two constraints are typical faithfulness constraints, requiring faithfulness of the output to its corresponding input. In contrast, NuC in (27c) and NoCODA in (27d) are markedness constraints, requiring unmarked syllable structure. According to Nuc, syllables must have a nucleus, and according to NoCODA, they should not have codas (see Prince \& Smolensky 1993 and McCarthy \& Prince 1993 for detailed accounts of the syllable structure in OT).

(27) Constraints for core syllables

a. MAX: No deletion of segments

b. DEP(ə): No schwa epenthesis

c. NuC: Syllables have nuclei.

d. NoCodA: Syllables have no coda.

Tableau (28) shows a monosyllabic word with no complications, just an onset, a nucleus and a coda. Candidates are first generated and then evaluated by the constraint hierarchy, though the tableau shows both steps at once. The candidate best satisfying the hierarchy is the optimal, grammatical one. In this case, candidate a. with [1] as the coda is the optimal one. Candidates b. and c., with loss of a consonant and with an epenthetic vowel, are eliminated by high-ranking $\operatorname{MAX}$ and $\operatorname{DEP}(\partial)$, respectively. Candidate $d$. is suboptimal because there is a syllable without a nucleus and this is dispreferred, at least when no higher-ranking constraint forces this choice, as illustrated in the next tableau. 
(28) Tableau for sol 'ground'

\begin{tabular}{|c|c|c|c|c|}
\hline$/ \mathrm{sç} 1 /$ & MAX & DEP(ə) & NuC & NoCoDA \\
\hline $\begin{array}{cc}\text { a. } & \sigma \\
& / / \backslash \\
& \text { s ç } 1\end{array}$ & & & & $*$ \\
\hline $\begin{array}{cc}\text { b. } & \sigma \\
& \Lambda \\
\text { s ç }\end{array}$ & $* !$ & & & \\
\hline $\begin{array}{ccc}\text { c. } & \sigma & \sigma \\
& \wedge & \wedge \\
& \mathrm{s} c ̧ & 1 \partial \\
\end{array}$ & & $* !$ & & \\
\hline 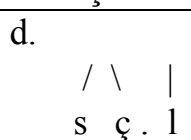 & & & $* !$ & \\
\hline
\end{tabular}

A monosyllabic word like calme has a final consonant which cannot be part of the phonological coda because of the restriction on the number of rime positions. This has just been posited so far, but will be motivated below.

In order to account for this kind of input, the additional constraints in (29) are needed. Tableau (30) illustrates the effect of the constraints. These constraints are undominated. In particular they dominate MAX and DEP, which can marginally be violated by optimal candidates. ${ }^{6}$ First, SONHIER is a complex constraint to the effect that syllables obey the Sonority Sequencing Principle, formulated in (22). BIMOR restricts the number of moras in a syllable rime to two. And PARSE-SEg forces segments to be parsed into syllables. All the constraints used so far have been introduced by Prince \& Smolensky (1993).

(29) Constraints for semisyllables

a. SONHIER: The margins of the syllable only consist of segments of decreasing sonority from the nucleus to the periphery.

b. BIMoR: Syllable rimes are maximally bimoraic (or the rime consists of maxially two positions).

c. PARSE-Seg: Segments belong to syllables.

\footnotetext{
Dell (1995) observes that only sonorants after a stop can be unrealized in the onset of a semisyllable. Quatre 'four' can be realized as [kat] and arbre 'tree' as [arb]. This realization is more probable in frequent words than in not so frequent ones, like bacle 'botch' or ocre 'ochre'. The pronunciation without a sonorant is mostly heard before words which begin with one or two consonants, as in quat' garçons 'four boys', un arb' plein d'pommes 'a tree full of apples'.
} 
(30) Tableau for calme 'quiet'

\begin{tabular}{|c|c|c|c|c|c|c|c|}
\hline$/ \mathrm{kalm} /$ & \begin{tabular}{|l|} 
SONHIER \\
\end{tabular} & BIMOR & PARSE-SEG & MAX & DEP(ə) & NuC & NOCODA \\
\hline $\begin{array}{ccc}\text { a. } & \sigma & \sigma \\
\mid & || & \mid \\
\mathrm{k} a \mathrm{l} & \mathrm{m}\end{array}$ & & & & & & * & $*$ \\
\hline 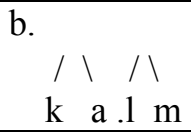 & $* !$ & & & & & & \\
\hline $\begin{array}{cc}\text { c. } & \sigma \\
/ / \backslash \backslash \\
\text { k a } 1 \mathrm{~m}\end{array}$ & & $* !$ & & & & & $* *$ \\
\hline $\begin{array}{c}\text { d. } \sigma \\
/ / \backslash \\
\mathrm{k} \text { a } 1 . \mathrm{m}\end{array}$ & & & $* !$ & & & & * \\
\hline $\begin{array}{c}\sigma \\
/ \mid \backslash \\
\mathrm{k} \text { a } 1 .\end{array}$ & & & & $* !$ & & & * \\
\hline $\begin{array}{ccc}\text { f. } & \sigma & \sigma \\
& / \| & / \\
\text { k a } & \text { l. m }\end{array}$ & & & & & $* !$ & & $*$ \\
\hline
\end{tabular}

In French, sequences of segments can be resyllabified across word boundaries, as is well known from the phenomena of liaison and enchaînement. As a consequence, semisyllables are prone to become onsets of following word initial onsetless syllables. This is also true of simple codas in words without semisyllables.

\section{Length and lengthening}

A short lax vowel is monomoraic, a tense vowel or a nasal vowel is bimoraic. Bimoraicity is not automatically associated with length, but determines the number of tautosyllabic postvocalic consonants (see also Plénat 1987). Tenseness and laxness are also orthogonal to length. Lax vowels can be long, and tense vowels can be short.

Some dialects of French have remnants of an earlier stage of the language in which, beside other properties, vowels were contrasted by length. The contrast is only possible in the final syllable of a Phonological Phrase. Notice, however, that bimoraic vowels, i.e. tense [o], [ø] and the nasal vowels (see below for a motivation of this claim), do not contrast in moraicity. They are always bimoraic. 
(31) Lexical contrasts in the vowel length (dialectal)

\begin{tabular}{llll}
\multicolumn{1}{c}{ short } & long & short & long \\
a. il 'he' & île 'island' & abime 'damages' & abîme 'abyss' \\
b. cru 'raw' & crue 'believed, fem.' & su 'known' & sue 'known, fem.' \\
c. bette 'beet' & bête 'beast' & mettre 'put' & maître 'master' \\
d. bout 'end' & boue 'mud' & loup 'wolf' & loue 'rent' \\
e. mal 'bad' & mâle 'male' & patte 'paw' & pâte 'dough'
\end{tabular}

Beside this lexical contrast, two kinds of "vowel lengthening" have been identified in the literature.

- First, all vowels are long before a final voiced fricative [v, z, 3, $\mathrm{s}]$, as illustrated in (32a).

- Second, the bimoraic vowels (tense $[0, \varnothing]$ and the nasal vowels) are long before all final consonants $(32 b):^{7}$

(32) Contexts of long vowels (Fouché 1959, Léon 1972, Malmberg 1969, Plénat 1987)

a. All vowels are long before a final voiced fricative $[\mathrm{v}, \mathrm{z}, 3, \mathrm{~s}]$ :

cave [ka:v] 'cellar', lève [le:v] 'lifts', chose [ [o:z] 'thing', sauge [so:3] 'sage', nage [na:3] 'swims', beurre [bœ:s] 'butter', lard [la:s] 'bacon'

b. Some vowels (tense $[\mathrm{o}, \varnothing]$ and the nasal vowels) are long before all final consonants:

ôte [o:t] 'takes away', saule [so:1] 'willow', heureuse [øьø:z] 'happy', meute [mø:t]

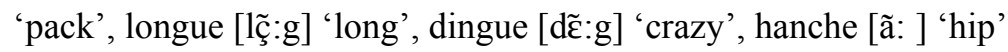

The lengthening affects only the last vowel of the last word in the Phonological Phrase, as illustrated in (33).

$$
\begin{array}{ll}
\text { c'est lourd [u:] 'it's heavy' } & \text { le lourd }[\mathrm{u}] \text { camion 'the heavy truck' } \\
\text { pauvre [o:] 'poor' } & \text { pauvrement [o] 'poorly' } \\
\text { il est à la cave [a:] 'he is in the cellar' } & \text { la cave [a] à vin 'the wine cellar' }
\end{array}
$$

The question sometimes raised as to whether the lengthening observed in French is phonological or phonetic does not find a clear answer. Marc van Oostendorp (p.c.) observes that many languages, such as Scottish English and some dialects of Dutch, have the same kind of vowel lengthening before voiced fricatives, which is often characterized

7 It is sometimes claimed that $[\mathrm{a}]$ is also lengthened. However, this lengthening is probably part of the lexical contrast illustrated in (31). 
as phonetic. Plénat (1987) suggests that the length of tense and nasal vowels (32b) is more phonological than the length of all other vowels before a voiced fricative (32a). This is also confirmed by O'Shaughnessy (1981), who finds that vowels are longer in contexts such as in (32b) than those in (32a).

The present paper concentrates on an OT account of the facts described above and leaves aside the question of the nature of the lengthening. In the framework developed so far, vowel lengthening finds a natural explanation: vowels are long in a prepausal open syllable - thus in the final syllable of a Phonological Phrase. Pairs like those in (34) confirm this hypothesis. The final vowels followed by two consonants, as in (34a), are short. These vowels are in closed syllables, since the first of the two final consonants closes the syllable. Note that the two consonants in (34a) cannot form an onset together since the second consonant is of a sonority equal to or lower than that of the first one. In contrast, the final vowels followed by one voiced fricative, as in (34b), are long. They are in open syllables followed by a semisyllable (see also Charette 1991 for an insightful and detailed analysis of such contrasts in the framework of Government Phonology).

(34) Short stressed vowels in closed syllables vs. long stressed vowels in open syllables (see also Charette 1991)
a. Short vowel
b. Long vowel

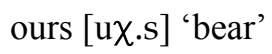
lourd [lu:.s] 'heavy'
heurte $[œ \chi . t]$ 'hurts'
meurt [mœ:.в] 'dies'

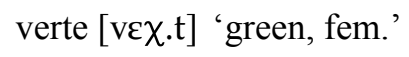
vert [vع:..B] 'green, masc.'
serve [sعis.v] 'serves, subj.'
sert [sع:.ı] 'serves, ind.'

To account for vowel length in OT, we need additional constraints. FINALLENGTH in (35a) predicts that Phonological Phrase final full syllables are bimoraic. This constraint accounts for the fact that the lengthening affects only the last vowel of the last word in the Phonological Phrase. For closed syllables, bimoraicity is trivially fulfilled, but for final open syllables, however, the constraint says that vowels are bimoraic - thus long. In particular, this holds for the vowels immediately preceding a semisyllable and explains why some vowels are long even if they are phonetically closed by a consonant.

*LONGV in (35b) requires vowels to be short, the universally unmarked length for vowels. The constraints (35a) and (35b) are in a so-called Paninian relation: ${ }^{*}$ LoNGV is a general constraint, saying something about all vowels, whereas FINALLENGTH requires that vowels are long in PhP-final syllables - a specific environment. For FinALLENGTH to have an effect, it must be ranked above *LoNGV, otherwise *LONGV would eliminate long vowels in all environments. Overgeneralizing somewhat, it will be assumed in the following that all bimoraic vowels are long.

CODACOND in (35c) is a language-dependent constraint (Itô 1989, Prince \& Smolensky 1993) prohibiting certain segments or classes of segments in the coda, in the case of French the voiced fricatives. If high ranking, it classifies all voiced fricatives as onsets. 
In particular, the word-final voiced fricatives are forced to project a semisyllable, and (35a) forces a vowel preceding such a segment to be long.

Finally, $\operatorname{MAx}(\mu)$ requires that if a vowel is specified as bimoraic in the input, it will occupies two moras. This holds for nasal vowels and for tense mid vowels, ${ }^{8}$ as well as for the data in (31), at least in the dialects which have retained the contrast. As a consequence of the bimoraicity of these vowels, a wordfinal consonant following such a vowel is forced to project a semisyllable, since the vowel already occupies the two moras of the syllable.

(35) Constraints for vowel length

a. FinAlLength: PhP-final full syllables are bimoraic.

b. *LONGV (No long vowel): Vowels are short.

c. CODACOND: A voiced fricative is an onset.

d. $\operatorname{MAx}(\mu)$ : Moras from the input have correspondents in the output.

(36) Tableau for ours 'bear'

\begin{tabular}{|c|c|c|c|c|c|c|}
\hline /uRs/ & SONHIER & BIMOR & FINALLENGTH & CODACOND & NuC & * LONGV \\
\hline $\begin{array}{cc} & \mu \mu \\
& || \\
& \text { a. } \quad \text { u } \chi . s\end{array}$ & & & & & $*$ & \\
\hline 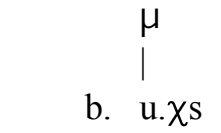 & $* !$ & & * & & * & \\
\hline $\begin{array}{ll} & \mu \mu \\
& \backslash / \\
\text { c. } \quad \text { u. } \chi_{\mathrm{s}}\end{array}$ & $* !$ & & & & $*$ & * \\
\hline $\begin{array}{c}\mu \mu \mu \\
\backslash / \mid \\
\text { d. } u \chi x . s\end{array}$ & & $* !$ & & & $*$ & * \\
\hline
\end{tabular}

Tableau (36) for ours illustrates why, given the constraint hierarchy assumed in the tableau, candidate $\mathrm{a}$. is optimal. Voicing assimilation between $/ \mathrm{R} /$ and $/ \mathrm{s} /$ is assumed without comment. ${ }^{9}$ Tableau (37) shows that even though it is relatively low ranking,

8 Tense and nasal vowels could also be rendered long through the effect of a special constraint forcing these vowels to be long in the output, thus replacing the faithfulness analysis by a pure markedness one.

9 Obstruent clusters in French always agree in voicing. I assume that the constraint UNIFORMITY, proposed by Lombardi (1999) to this effect, is undominated in French. It may be interesting to mention that French patterns with Yiddish in Lombardi's typology. 
CODACOND is fulfilled in a word like lourd, in which the last consonant is a voiced fricative.

(37) Tableau for lourd 'heavy'

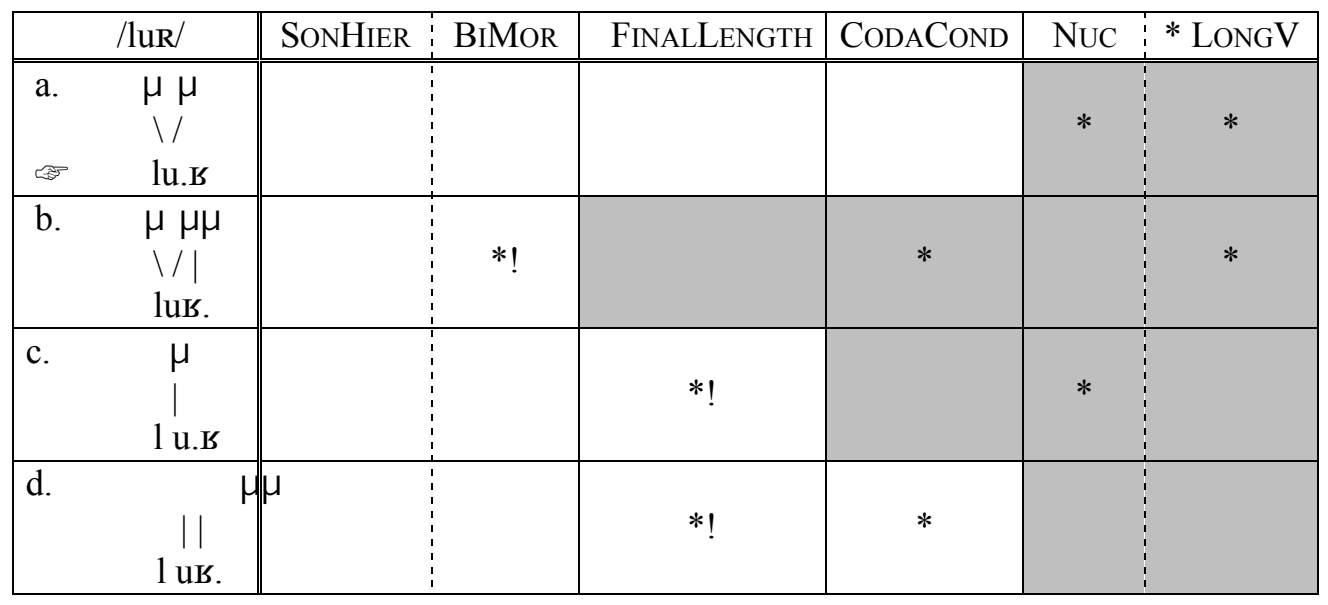

Tableau (38) shows the working of $\operatorname{MAx}(\mu)$ for lexically long vowels. The motivation for analyzing the tense and the nasal vowels as intrinsically bimoraic is twofold. First, as was mentioned in the preceding section, these vowels lengthen before all final consonants. This is expected if they are bimoraic. ${ }^{10}$ Any subsequent consonants are relegated into a following semisyllable, since the two moras of the last full syllable of the word are made up by the vowels. The second reason is that whenever two consonants follow these vowels word finally they are of rising sonority. Recall that words like

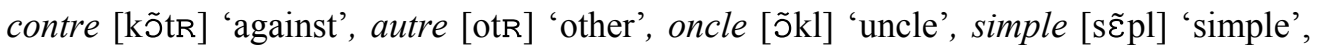
etc., are frequent, but there are no words like *conrte [kõRt], *aurte [ort], *onlque, [õlk], etc. in which the sonority of the two consonants is falling (see (26)). I take this distribution as an argument for the fact that the postvocalic consonants must form an onset in these words and are not distributed over the coda and the following onset. Again, this is what is expected if the nasal vowels and [o] and [ø] are bimoraic.

10 See Féry (1997) for an analysis of the German vowels along the same lines. In German, lax vowels are monomoraic and tense ones are bimoraic. Since stressed syllables are mandatorily bimoraic, stressed lax vowels are always in closed syllables. 
(38) Tableau for contre 'against'

\begin{tabular}{|c|c|c|c|c|c|c|}
\hline $\begin{array}{c}\mu \mu \\
V \\
/ \mathrm{k} \tilde{\mathrm{ç}} \mathrm{t \chi} /\end{array}$ & $\operatorname{MAx}(\mu)$ & SONHIER & BIMOR & MAX & DEP(ə) & *LONGV \\
\hline $\begin{array}{c}\mu \mu \\
\backslash / \\
\text { a. }[k \tilde{c} . t x]\end{array}$ & & & & & & * \\
\hline 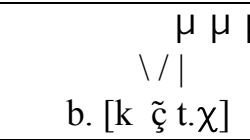 & & & $* !$ & & & * \\
\hline 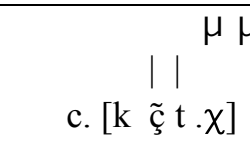 & *! & & & & & \\
\hline
\end{tabular}

The question as to why some preconsonantal final vowels can be long, but not all, finds an explanation in this framework. Vowels can be long only when phrase-final and in an open syllable, or in front of a semisyllable. Semisyllables arise in the following cases. First, some consonants are preferably onsets. Voiced fricatives in the final position are always onsets of semisyllables, which implies that a preceding vowel is always in an open syllable: cave is syllabified as [ka:.v]. This accounts for (32a). Second, some vowels are intrinsically bimoraic. This is true of tense vowels and of nasal vowels, both of which are long when stressed. Since syllables are maximally bimoraic, a following consonant obligatorily projects a semisyllable: ôte 'takes away' is syllabified as [o:.t]. This explains (32b).

A final remark in relation to the lengthening facts: there is a tendency in French to eliminate the semisyllables and to integrate the final consonants into the coda of the preceding syllable. A word like même 'even', which is sometimes pronounced with a long vowel [me:.m], is often realized with a short one [mem], which allows the final [m] to be the coda of the syllable, instead of being relegated into a semisyllable. As a result, length contrasts like those illustrated in (31) are being lost. Many dialects, like the Parisian one, seem to have lost the length contrast entirely. There is no trace of a lexical length contrast anymore.

\section{Tense and lax mid vowels in OT}

This section returns to the tense and lax vowels and proposes an OT account of their distribution. It was shown in section 2 that the general tendency for tense vowels is to be long and in an open syllable, whereas lax vowels tend to be short and in a closed syllable. However, as was shown in the preceding section, there is also a tendency for all 
final vowels to be long, regardless of their quality. For tense vowels, no contradiction arises, whereas for lax vowels in open syllables, there is a conflict. The requirement for stressed syllables to be bimoraic is generally stronger (though remember the optionality of the lengthening process). Lax vowels avoid open syllables, but when they are in a final open syllable before a semisyllable, they can be long. This kind of conflict is hard to express in derivational models which derive surface forms from underlying representations with obligatory ordered rules. In OT, however, conflicts are expressed with ranked constraints, and since constraints are violable, it is expected that conflicts have to be solved one way or the other, depending on the input and on the ranking of the relevant constraints. As mentioned in the introduction, specific constraints have to be ranked higher than general ones in order to have an effect at all, and exemplifications of this principle will be shown in this section.

For the case at hand, the relevant constraints are those from the preceding sections and a new one, formulated in (39). ${ }^{11}$ Some additional constraints are vowel-specific and will be introduced below.

(39) LAXV: Lax vowels are monomoraic.

The ranking CodaCond, FinalLength $>>$ *LongV, LaxV accounts for the fact that some lax vowels emerge as long (see the tableau for or 'gold' below).

\subsection{The alternation between $[\mathrm{o}]$ and $[\mathrm{c}]$ in OT}

The distributional properties of [o] and [c] to be accounted for were formulated in (9) and are repeated in (40).

(40) Distribution of [o] and [ç]

a. Only [o] in an open syllable. Preferably [ç] in a closed syllable.

b. Only the tense back mid vowel [o] before [z].

c. Only the lax back mid vowel [ç] before voiced dorsal consonants.

d. Otherwise, in word-final position before a consonant, both variants are allowed.

These generalizations are organized from the general to the more specific and it will be shown how constraints must also be organized on a domination scale going from specific to general to account for them. We'll start with the more general tendency in (40a).

11 The question of which aspects of the vowels and/or the syllable structure are "underlying" and which are derived has been a much debated topic in generative phonology. Four possibilities have been considered at considerable length for languages such as Dutch and German: vowel quality, vowel length, moraic structure and syllable structure. This problem is by far not as crucial in OT, since in principle each of these properties can be part of the input as long as the constraint hierarchy guarantees that all relevant properties correlate with each other. 
The fact that only [o], and not [ç], is possible in an open final syllable is explained by the effect of LAXV, which demands that lax vowels be monomoraic. Since this contradicts the preference for vowels in final open syllables to be bimoraic, [o] is preferred, as shown in tableau (41) for kilo. Tense vowels are bimoraic and vowels in open final syllables are preferably bimoraic. Thus, there is no conflict. This is a case of the emergence of the unmarked (McCarthy \& Prince 1994). It is assumed that when the back vowel is final, its input is not specified for tenseness or laxness, nor is it specified for moraicity. A widely used way to express underspecification in OT is to allow for multiple inputs. The moras in parentheses show the number of moras associated with the final vowel. Both candidates with bimoraic vowels (a. and c.) violate the constraint against long vowels, but the two candidates with monomoraic vowels (b. and d.) violate higher-ranking FinALLENGTH, and are thus eliminated. Candidate $c$., with a bimoraic lax vowel, violates LAXV, as well, and candidate a., which only violates * LONGV, is the best candidate.

(41) Tableau for kilo 'kilo'

\begin{tabular}{|c||c|c|c|}
\hline /kilo, kilç/ & FINALLENGTH & LAXV & *LONGV \\
\hline \hline a. kilo $(\mu \mu)$ & & & $*$ \\
\hline b. kilo $(\mu)$ & $* !$ & & \\
\hline c. kilç $(\mu \mu)$ & & $* !$ & $*$ \\
\hline d. kilç $(\mu)$ & $* !$ & & \\
\hline
\end{tabular}

The candidates for the very interesting alternation sot/sotte in (42) consist of masculinefeminine adjective pairs. The best pair in tableau (42) is the first one, in which the masculine adjective has a tense vowel in an open syllable and the feminine adjective has a lax vowel in a closed syllable. ${ }^{12}$ The moraic structure is not given in the tableau, but it is assumed that LAXV is fulfilled in all candidates, and that tense [o] is always bimoraic.

12 It is not perfectly clear how to force the feminine forms to be in a closed syllable. One possibility could be to activate an additional constraint, called $\operatorname{FEM}(\mathrm{C})$, requiring feminine adjectives to end in a consonant. At first sight, this constraint is too language specific, but if it is understood as a special case of a more general constraint positing that the feminine forms are phonologically more complex than their masculine counterparts, it becomes universal after all. The fact that feminine is some kind of feature added to the unmarked gender - which is masculine - seems to be universal enough to elevate it to the status of a universal markedness constraint. A constraint requiring the masculine and the feminine to be different would, of course, not be enough. 
(42) Tableau for sot/sotte 'silly'

\begin{tabular}{|c||c|c|c|c|}
\hline$/$ so, sç, sot, sçt/ & FINALLENGTH & LAXV & NuC & NOCODA \\
\hline \hline a. .so./.sçt. & & & & $*$ \\
\hline b. .so./.so.t. & & & $* !$ & \\
\hline c. .sç./.sçt. & $* !$ & & & $*$ \\
\hline d. .sçt./.so. & & & & $*$ \\
\hline
\end{tabular}

An advantage of the account proposed here is that the quality of the vowel in the alternation is fully predictable. No assumption must be made about the underlying quality of the o-segment. The input consists of all combinatorial variants of the allophones found in this word, which again replaces underspecification of the relevant features.

Turning now to (40b), the fact that only [o] is found before $[\mathrm{z}]$ supports the analysis proposed above that voiced fricatives are onsets. If, in the words in (7a), [z] is the onset of a semisyllable, the preceding o-sound is in an open syllable and must be bimoraic, and thus tense, since it is the final vowel. Compare the tableau for lourd in (37).

However, some of the data in (7b), described in (40c), present a problem. First, vowels preceding $[R]$ are lax when they can be (when mid). This can be expressed by the constraint LAXINGHARMONY, which says that $[\mathrm{R}]$ is preceded by a lax vowel. This harmony between $[\mathrm{R}]$ and a preceding lax vowel is found in several languages, as for instance in some dialects of German (see Hiller 1995).

(43) LAXINGHARMONY: [R] is preceded by a lax vowel.

LAXV and FINALLENGTH, requiring [or], conflict with LAXINGHARMONY, which militates against a sequence [ов], since [o] is a tense vowel. In derivational phonology, this would be accounted for by ordered rules in a disjunctive relation. In OT, depending on which constraint is ranked higher, the sequence [çธ] or [ов] will be chosen. LAXINGHARMONY is ranked higher than CODACOND, which means that [ç $\mathrm{b}]$ is chosen. ${ }^{13}$ In this case the lax vowel is long, because FInALLENGTH is higher ranking than both LAXV and *LONGV. In other words, LAXINGHARMONY is more specific than CODACOND since it says something about one consonant and a class of vowels.

13 Notice that lourd in (37) is not affected by LAXINGHARMONY since there are no lax high vowels in standard French. This is accounted for by a cooccurrence restriction against [high, lax]. 
(44) Tableau for or 'gold'

\begin{tabular}{|c|c|c|c|c|c|}
\hline /çR, OR/ & $\begin{array}{l}\text { LAXING } \\
\text { HARMONY }\end{array}$ & FINALLENGTH & CODACOND & LAXV & *LONGV \\
\hline 呣 .ç:... & & & & * & * \\
\hline .ç.J. & & $* !$ & & & \\
\hline .о:.в. & $* !$ & & & & $*$ \\
\hline .OB. & *! & & $*$ & & \\
\hline .çธ. & & & $* !$ & & \\
\hline
\end{tabular}

The next context that we need to consider is the class of the four dorsal voiced consonants $[\mathrm{g}],[\mathrm{n}],[\mathrm{y}]$ and $[\mathrm{r}]$. As was shown in (7b), only [ç] is allowed before these consonants. Thus we need a constraint about an even more restricted class of segments: just one vowel and the voiced dorsal consonants. We can express this with the help of the constraint BACKNESS, as formulated in (45). This constraint must be ranked very high in the hierarchy. Notice that BACKNESS makes the same prediction as LAXINGHARMONY as far as [R] is concerned, but LAXINGHARMONY is more general since it also accounts for the laxing of the other mid vowels before [R]. It should be clear that due to the highranking of BACKNESS, only [ç] can appear before the voiced dorsal consonants.

\section{(45) BACKNESS}

Before a voiced dorsal consonant, only a lax back mid vowel is allowed $(*[\mathrm{o}]+$ voiced dorsal C).

The last series of cases are the most specific ones. Before most consonants, both variants of the back mid vowel are allowed. For these we need faithfulness to a property of a specific segment in a specific lexical item. A word like paume, as opposed to pomme (see (8)), in which the o-sound is always tense is accounted for by the lexically prespecified bimoraicity, or tenseness, of the vowel. The final consonant is relegated to a semisyllable. In pomme, no prespecification is needed. The segment [m] is the coda of the syllable, and the whole word is syllabified like sol in (28). 
(46) Tableau for paume 'palm'

\begin{tabular}{|c|c|c|c|c|c|}
\hline $\begin{array}{c}\mu \mu \\
\vee \\
/ \mathrm{pom} / \\
\end{array}$ & $\operatorname{MAx}(\mu)$ & BIMOR & FINALLENGTH & CODACOND & *LONGV \\
\hline $\begin{array}{cc}\text { a. } & \mu \mu \\
& \backslash / \\
& {[\mathrm{p} o . \mathrm{m}]}\end{array}$ & & & & & * \\
\hline $\begin{array}{cc}\text { b. } \quad & \mu \mu \mu \\
& \backslash / \mid \\
& {[p \circ \mathrm{o}]} \\
\end{array}$ & & *! & & & $*$ \\
\hline 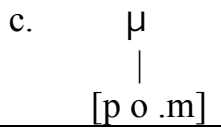 & *! & & * & & \\
\hline $\begin{array}{c}\mu \mu \\
|| \\
{[p \circ \mathrm{m}]}\end{array}$ & $* !$ & & & & \\
\hline
\end{tabular}

The constraint hierarchy given in (47) has been used to account for the alternation between the two round back mid vowels [o] and [o]. $\operatorname{MAx}(\mu)$ is the highest ranking constraint, responsible for the lexical length contrast on vowels. BACKNESS and LAXINGHARMONY are next on the hierarchy and are responsible for specific cooccurrence restrictions. The remaining constraints are relevant for the length of all vowels, not only the mid ones, and as such are responsible for what happens in the default cases.

(47) Constraint hierarchy for the round back mid vowels [o] and [0]

$\operatorname{MAX}(\mu)$, BIMOR $\gg$ BACKNESS, LAXINGHARMONY $>>$ FinALLENGTH $\gg$ CODACOND $>$ LAXV $>>$ NuC

NOCODA and *LONGVOWEL have been mentioned in the tableaux but will probably never play a role in choosing between the relevant candidates.

\subsection{The alternation between $[\varnothing]$ and $[\propto]$ in OT}

Examine next the second pair of mid vowels, $[\varnothing]$ and [œ]. First, recall the distributional properties to be accounted for. (16) is repeated as (48). 
(48) Distribution of $[\varnothing]$ and [œ]

a. Only $[\varnothing]$ in an open syllable. Preferably [œ] in a closed syllable.

b. Before a coronal obstruent, only $[\varnothing]$ is allowed.

c. Otherwise, in word-final position before a consonant, nearly only [œ].

The constraints used so far are sufficient for accounting for the first generalization, that is the fact that only the tense variant is found in open syllables and that [œ] is preferred in closed syllables. Tableaux (49) and (50) show how the distribution of [ø] and [œ] is obtained in the alternation between veut and veulent (open vs. closed syllable). The number of moras in parentheses stand for vowel moraicity.

(49) Tableau for veut 'want, 3rd pers. sg.'

\begin{tabular}{|c||c|c|c|c|}
\hline$/ \mathrm{v} \varnothing /, / \mathrm{v} /$ & BIMOR & FINALLENGTH & LAXV & *LONGV \\
\hline \hline a. .vø. $(\mu \mu)$ & & & & $*$ \\
\hline b. .vœ. $(\mu)$ & & $* !$ & & \\
\hline c. .vœ. $(\mu \mu)$ & & & $* !$ & $*$ \\
\hline
\end{tabular}

(50) Tableau for veulent 'want, 3rd pers. pl.'

\begin{tabular}{|c||c|c|c|c|}
\hline$/$ vøl/, /vœl./ & BIMOR & FINALLENGTH & LAXV & *LONGV \\
\hline \hline a. .vøl. $(\mu \mu)$ & $* !$ & & & $*$ \\
\hline b. .vœl. $(\mu)$ & & & & \\
\hline
\end{tabular}

The second generalization in (48b) posits that only tense $[\varnothing]$ is allowed before a coronal obstruent. To account for [ø] before [z] or [3] (as in Maubeuge), no new constraint is needed. Since the voiced fricative is preferably an onset, the tense variant is expected.

(51) Tableau for gueuse 'lass'

\begin{tabular}{|r||c|c|c|c:c|c|}
\hline /gøz, gœz/ & BIMOR & CODACOND & LAXV & $*$ LONGV & NuC & NoCODA \\
\hline \hline a. .gø:.z. $(\mu \mu)$ & & & & $*$ & $*$ & \\
\hline b. .gøz. $(\mu \mu)$ & $* !$ & $*$ & & & & $*$ \\
\hline c. .gœ.z. $(\mu \mu)$ & & & $* !$ & $*$ & $*$ & \\
\hline d. .gœz. $(\mu)$ & & $* !$ & & & & $*$ \\
\hline
\end{tabular}

However, for words like émeute, feutre, and Eudes, with a coronal stop after the tense [ø], an additional, higher-ranking constraint is needed to account for the lack of [œ] before coronals, like the one in (52). This constraint conflicts with the other constraints responsible for the alternation between tense and lax vowels, since a vowel followed by a consonant other than a voiced fricative should form a closed syllable, in which case the lax variant of the vowel is expected. The effect of *[œ]CORONAL is illustrated in (53). 
(52) *[œ]CORONAL

Before a coronal obstruent, only the tense variant of the front mid round vowel is allowed.

(53) Tableau for meute 'pack'

\begin{tabular}{|c||c|c|c|c:c|}
\hline /møt, mœt/ & $*[œ]$ COR & CODACOND & LAXV & *LONGV & NUC \\
\hline \hline a. .mø:.t. & & & & $*$ & $*$ \\
\hline b. .mœ:.t. & $* !$ & & $*$ & $*$ & $*$ \\
\hline c. .mœt. & $* !$ & & & & \\
\hline
\end{tabular}

Words like veuve and meuble, which have a lax vowel in a context where a tense vowel is expected, are accounted for by a constraint prohibiting [ø], ranked below * [œ]CORONAL. These constraints are in a clear Paninian relationship, since (54) prohibits $[\varnothing]$ in all contexts and $*[œ]$ CoRONAL prohibits the lax variant in a specific context.

$(54) *[\varnothing]$

Finally, for the speakers who have the contrasts jeuneljeûne or meule/meule (cf. (14)), a specific faithfulness constraint, like $\operatorname{MAX}(\mu)$, is needed by means of which the contrasting quality of the vowels can be maintained. The contrast must be lexically specified.

The same kind of constraint hierarchy as the one which has been shown to be active in the alternation between the back mid vowels has been established here. The most specific constraints are of course different from the ones for [o] and [o], except for the one responsible for preserving the lexical prespecification of the moras.

(55) Constraint hierarchy for the round front mid vowels [ø] and [œ]

$\operatorname{MAx}(\mu)$, BiMor $>>*[$ e $]$ CORONAL $>>*[\varnothing]>$ FInALLENGTH $>$ CODACOND $>>$ LAXV $>$ NuC

\section{3 The alternation between $[\mathrm{e}]$ and $[\varepsilon]$ in OT}

This section examines the last pair of mid vowels, the unrounded front ones, [e] and $[\varepsilon]$. The generalizations are repeated from (20).

(56) Distribution of $[e]$ and $[\varepsilon]$

a. Both $[\mathrm{e}]$ and $[\varepsilon]$ in an open syllable.

b. No [e], but always $[\varepsilon]$ before a final consonant. [e] is allowed only in an open syllable. 
Just one additional constraint is needed which prohibits word-final [e] before all consonants, tautosyllabic or not. It is formulated in (57). This constraint aims at blocking the emergence of $[\mathrm{e}]$ in a phonetically closed syllable.

(57) *[e]C: No word-final [e] before a consonant

If this constraint is ranked higher than the constraint against long lax vowels, it will block the emergence of [e] before a voiced fricative, where a long vowel is expected, as required by CODACOND and FinALLENGTH.

(58) Tableau for beige 'beige

\begin{tabular}{|c||c|c|c|c|c|c|}
\hline$/$ bez, be3/ & $*[\mathrm{e}] \mathrm{C}$ & FINALLENGTH & CODACOND & LAXV & *LONGV & NUC \\
\hline \hline a. be.3 $(\mu)$ & & $* !$ & & & & $*$ \\
\hline b. be.3 $(\mu \mu)$ & & & & $*$ & $*$ & $*$ \\
\hline c. be.3 $(\mu)$ & $* !$ & $*$ & & & & $*$ \\
\hline d. be.3 $(\mu \mu)$ & $* !$ & & & & $*$ & $*$ \\
\hline
\end{tabular}

The fact that both [e] and $[\varepsilon]$ are contrastive in the word-final position can be accounted for by the faithfulness constraint $\operatorname{MAX}(\mu)$. Note that the quality of this vowel is subject to a great deal of variation and has been the theme of extensive studies, such as Martinet \& Walter (1973).

However, the tendency to have lax vowels in closed syllables and tense vowels in open syllables can be observed in pairs of related words, like taper/tapette. In the open syllable, the tense variant is realized, and in the closed syllable the lax variant. The relevant environment is somewhat blurred by other influences, like the admissibility of both sounds in the absolute final position, the lexical resemblance and the neutralization of the vowel quality in nonfinal syllables (see Léon 1972).

(59) Constraint hierarchy for the mid front unrounded vowels [e] and [ $\varepsilon]$

$$
\operatorname{MAX}(\mu), *[\mathrm{e}] \mathrm{C}, \mathrm{BIMOR}>>\text { FinaLLENGTH }>>\text { CODACOND }>>\text { LAXV }>>\text { NuC }
$$




\section{Conclusion}

The generalization expressed in (1) stating that lax vowels occur in closed syllables and tense vowels in open ones holds in French, though it is obscured by a number of idiosyncrasies mostly having to do with restrictions between classes of segments or even between particular vowels and consonants. The analysis advanced in this paper relies heavily on the existence of semisyllables, which have been shown to be necessary in the phonology of several languages (see, for example, Cho \& King 2002 for Georgian, Polish and Bella Coola, Féry 2002 for German and Green 2002 for Irish).

OT is an ideal framework to account for the intricate data presented above, since the effect of unmarkedness can be overridden by more specific constraints acting toward more markedness. The constraints necessary to account for French are listed in (60).

(60) Constraint ranking for French

SonHier, BiMor, Max $(\mu), *[\mathrm{e}] \mathrm{C}>>$ LaXingHarmony, *[œ]Coronal $>>$ *[ø], MaX, DeP(ə), FinalLength $>$ CODACOND $>$ LaXV $>$ * LongV, NuC $>>$ NoCODA

The constraints relevant for the distribution of pairs of lax and tense vowels are in a Paninian relationship, with the more specific ones ranked higher than the less specific ones. Constraints aiming at preserving lexical prespecifications must be ordered highest in the hierarchy; then we find constraints involving classes of segments, and at the bottom of the hierarchy we find the most general constraints. The more specific constraints we find, the less probable that the general ones will play be active in determining the optimal candidates, and the less we see the effects of Emergence of the Unmarked. In French, the unmarked case for the occurrence of vowels is that a lax vowel is closed by a consonant and a tense vowel is in an open syllable. Since this pattern is observed in a number of other languages as well, we can safely conclude that we are dealing with a truly universal tendency. In languages in which the constraints requiring fulfillment of these tendencies are highly ranked, as in many Germanic languages, their effects are more immediately observable than in languages like French, where a whole series of higher-ranking constraints obliterate their effects. 


\section{References}

Anderson, Stephen R. (1982). The analysis of French schwa: Or, how to get something from nothing. Language 58. 534-573.

Basbøll, Hans (1978). Schwa, jonctures et syllabification dans les représentations phonologiques du français. Acta Linguistica Hafniensa 16. 147-182.

Bouchard, D. (1980). A voice for 'e muet'. Journal of Linguistic Research 1(4). 17-47.

Charette, Monik (1991). Conditions on phonological government. Cambridge: Cambridge University Press.

Cho, Young-mee Yu \& Tracy Holloway King (2002). Semisyllables and Universal Syllabification. In: Caroline Féry \& Ruben van de Vijver (eds.) The Syllable in Optimality Theory. Cambridge: Cambridge University Press.

Clements, G. N. (1990). The Role of the Sonority Cycle in Core Syllabification. In: J. Kingston and M. Beckman (eds.) 283-333.

Delattre, Pierre (1957). La question des deux 'a' en français. The French Review 31(2). 141-148. Reprinted in Delattre 1966. 208-214.

Delattre, Pierre (1966). Studies in French and Comparative Phonetics. The Hague: Mouton.

Dell, François (1995). Consonant Clusters and Phonological Syllables in French. Lingua 95. 5-26.

Féry, Caroline (1997). The mora as a measure of weight and a syllabic constituent. In: P. M. Bertinetto, L. Gaeta, G. Jetchev \& D. Michaels (eds.) Certanem Phonologicum III. Papers from the Third Cortona Phonology Meeting. Torino: Rosenberg \& Sellier. 91-110.

Féry, Caroline (2001). Focus in French. In: Caroline Féry \& Wolfgang Sternefeld (eds.) Audiatur Vox Sapientiae: A Festschrift for Arnim von Stechow. Berlin: AkademieVerlag. 153-181.

Féry, Caroline (2002). Nonmoraic syllables in German. In Caroline Féry \& Ruben van de Vijver (eds.) The Syllable in Optimality Theory. Cambridge: Cambridge University Press.

Fouché, P. (1959). Traité de prononciation française. 2nd ed. Paris: Klincksieck.

Green, Antony Dubach (2002). Extrasyllabic Consonants and Onset Well-Formedness. In: Caroline Féry \& Ruben van de Vijver (eds.) The Syllable in Optimality Theory. Cambridge: Cambridge University Press.

Hammond, Michael (1997). Vowel Quantity and Syllabification in English. Language 73. 1-17.

Hiller, Markus (1995). Regressive Pharyngalisierung im Stuttgarter Schwäbischen. Linguistische Berichte 155. 33-64.

Hulst, Harry van der (1984). Syllable structure and stress in Dutch. Dordrecht: Foris.

Itô, Junko (1989). A prosodic theory of epenthesis. Natural Language and Linguistic Theory 7. 217-259. 
Kager, René (1989). A metrical theory of stress and destressing in English and Dutch. Dordrecht: Foris.

Léon, Pierre R. (1972). Prononciation du français standard. Aide mémoire d'orthoépie à l'usage des étudiants étrangers. Paris: Didier.

Lombardi, Linda (1999). Evidence for MaxFeature constraints from Japanese. Natural Language and Linguistic Theory.

McCarthy, John J. \& Alan S. Prince (1993). Prosodic Morphology I: Constraint Interaction and Satisfaction. Ms. University of Massachusetts, Amherst, and Rutgers University, New Brunswick, NJ.

McCarthy, John J. \& Alan S. Prince (1994). The Emergence of the Unmarked: Optimality in Prosodic Morphology. In Mercè Gonzalez (ed.) Proceedings of the North East Linguistic Society 24. Amherst, MA: Graduate Linguistic Student Association. 333-379.

Malmberg, Bertil (1969). Phonétique française. Lund: Liber Läromedel.

Martinet, André \& Henriette Walter (1973). Dictionnaire de la prononciation française dans son usage réel. Paris: France-Expansion.

Meisenburg, Trudel \& Maria Selig (1998). Phonetik und Phonologie des Französischen. Stuttgart: Klett Verlag.

Morin, Yves-Charles (1987). The status of mute 'e'. Studies in French Linguistics 1(2). 79-140.

Morin, Yves-Charles (1988). De l'ajustement de schwa en syllabe fermée dans la phonologie du français. In: P. S. Verluyten (ed.) La phonologie du schwa française. Amsterdam: Benjamins. 133-189.

Moulton, William G. (1962). The Sounds of English and German. Chicago: University of Chicago Press.

Noske, Roland (1984). Syllabification and Syllable Changing Rules in French. In: H. van der Hulst \& N. Smith (eds.) The structure of phonological representation. Part II. Dordrecht: Foris. 257-310.

Oostendorp, Marc van (1999). Phonological Projection: A Theory of Feature Content and Prosodic Structure. Berlin: Mouton de Gruyter.

O'Shaughnessy (1981). A study of French vowel and consonant durations. Journal of Phonetics 9. 385-406.

Plénat, Marc (1987). On the structure of rime in Standard French. Linguistics 25. 867887.

Prince, Alan \& Paul Smolensky (1993). Optimality Theory: Constraint interaction in generative grammar. Univ. of Colorado, Boulder.

Rialland, Annie (1986). Schwa et syllables en français. In: Leo Wetzels \& Engin Sezer (eds.) Studies in Compensatory Lengthening. Dordrecht: Foris. 187-226.

Rialland, Annie (1999). The phonology and phonetics of extrasyllabicity in French. In: P. A. Keating (ed.) Phonological Structure and Phonetic Form. Papers in Laboratory Phonology 3. Cambridge: Cambridge University Press.

Tranel, Bernard (1987). The Sounds of French: An Introduction. Cambridge: Cambridge University Press. 
Tranel, Bernard (1995). French Final Consonants and Nonlinear Phonology. Lingua 95. 131167.

Vennemann, Theo (1986). Neuere Entwicklungen in der Phonologie. Berlin/New York/Amsterdam: Mouton De Gruyter.

Wiese, Richard (1996). The phonology of German. Oxford: Clarendon Press.

Caroline Féry (fery@rz.uni-potsdam.de)

Institute of Linguistics- University of Potsdam

Postfach 201553

14415 Potsdam - Germany 